\title{
The Relationship between Physical Activity Level and Exam Anxiety Level in University Students: A Cross-Sectional Study
}

\author{
Umit Yalçın \\ Specialist Doctor in Physical Medicine and Rehabilitation, Medicana International Hospital Istanbul, \\ Beylikdüzü, Istanbul, Turkey
}

\begin{abstract}
Introduction: Anxiety, depression and other mental problems are one of the important health problems on university campuses. The anxiety created by the exams in the students negatively affects the students' attitude and success towards the lessons. The studies carried out, the understanding the relationship between exercise, depression and anxiety, and positive results obtained were satisfying and also increased the value given to this issue. In our study, we examined the relationship between university students' physical activity level and exam anxiety.

Material-Method: This cross-sectional study was conducted with 175 volunteer university students who did and did not do sports. The International Physical Activity Assessment Questionnaire (IPAQ) Long Form was used to measure the level of physical activity and the Exam Anxiety Inventory to determine the level of anxiety.
\end{abstract}

Results: The rate of female patients was significantly higher in the inactive group than the minimally active and active group $(\mathrm{p}<0.05)$. In the inactive group, the test anxiety score was significantly higher $(\mathrm{p}$ $<0.05)$ than the minimally active and active group.

Conclusion: As a result, our research revealed that the physical activity levels of university students are quite low, especially in female students, and there is a relationship between the level of physical activity and anxiety.

Keywords: Activity, Anxiety, Student, depression, physical function, university

\section{Introduction}

The fact that universities, act as besides providing young people with a profession, determinants of their social, cultural, economic and personal development affects the perception of both societies and individuals as their favorite institutions. However, in the process of entering university in our country, aside from stresses during the adaptation of students and families to the new applications they encounter in the education system, going through a long, tiring and economically expensive process makes this process even more tense. Moreover, in the cities far away from the families of many of the young people who are placed in universities, the necessity to live their lives, make friends, get used to the new city and culture, the new school and its responsibility increase the rates of stress and anxiety. According to Mowbray et al., depression and other mental problems are one of the major health problems on university campuses (1). Researches emphasize that stress is related to increased physical and mental disorders (2). Lifelong physical activity is an important indicator of healthy lifestyle and there are many publications in the literature that show that active lifestyle prevents chronic diseases and obesity. Regular physical activity reduces the risk of some health problems by preventing obesity and cardiovascular diseases, and plays a role in the prevention and treatment of some types of cancer $(3,4)$. Anxiety, which is one of the basic emotions, is a part of a person's daily life. Anxiety situation is handled in the literature in two forms, namely state and continuity. Constant anxiety arises from the individual's personality trait. State anxiety is the expectation of the negative result that an individual feels in the face of any specific situation. The negative result expectation that the students feel about the exams is an example of an important state anxiety. Exams are important processes in shaping students' lives. This situation can increase students' anxiety. Anxiety caused by exams in students negatively affects the students' attitude and success towards the lessons. 
In many studies conducted abroad, anxiety of exams has been seen to decrease the exam performance of the individual $(5,6)$. There are studies linking musculoskeletal disorders and psychological and psychosomatic symptoms such as depression and anxiety in adolescents. Depression, anxiety, psychosomatic symptoms (headache, stomach pain) are among the factors frequently associated with musculoskeletal disorder in adolescents. Anxiety and depression also cause sleep problems in adolescents (7). The efforts of protecting young people studying at the university from depression and anxiety or rescuing students from negative moods has become a topic that attracts researchers. Among the work done for this purpose, understanding of the relationship between exercise, depression and anxiety and the positive results obtained are to be satisfying, also increased the value given to this subject. Findings that can be reached in the literature review related to the relationship between the levels of physical activity, depression and anxiety of young people studying at the university explain the importance and necessity of this study which was made Gerber et al. They investigated the relationship between, aerobic sports, ball sports, dance activity and resistance exercises with stress and depression with university students; as a result of the research, they found that participating in ball sports and dance activities reduced stress and depression symptoms, resistance exercises were associated with low depression symptoms and low stress perception, and aerobic sports had no effect on stress regulation (8). Thome et al, found that there is a positive relationship between their psychological health and physical activities of female students at the university (9). On the other hand, in another study conducted with girls studying at the university, a program consisting of aerobic exercise, resistance exercise and control group was applied; as a result of the research, it was observed that the depression level of the group exercising aerobics decreased significantly compared to the others (10). Beside to these researches, in the literature, research findings on the relationship between exercise and suicidal tendency that comes with depression have been found. In a study conducted with 1622 students studying in universities in the Midwest, North West, and Canada, it was found that the rate of suicide in boys (13\%) was higher than in girls $(10 \%)$, although the frequency of depression was similar in boys and girls (11). In addition, young people with a tendency to depression were given regular exercises, and as a result, it was seen that depression and exercise studies functioned inversely, and regular exercises decreased the rate of depression and suicide. Inactivity, which is common in today's world, increases the risk of obesity, which causes fatal diseases such as cardiovascular diseases and diabetes. Today, anxiety and depression are as common as obesity and decrease our quality of life and efficiency. Studies conducted in recent years offer dells that physical activity can prevent depression and anxiety. Therefore, the purpose of this study is to determine the level of physical activity in university students and to evaluate the relationship between this level and anxiety.

\section{Methods}

Participants: This cross-sectional study was carried out with 175 volunteer university students who did and did not do sports in different faculties and schools of Beykoz University. Local ethics committee approval was obtained for the study protocol and students were randomly selected. The groups were formed with the students who were interviewed at the faculties and those who agreed to work, until the quorum was reached, and the informed consent was obtained from the students who participated in the study. The study was carried out in accordance with the principles of the Helsinki Declaration. The study was carried out 1 week before the exams, which we think will be high in exam anxiety. Sociodemographic form in which students' age and gender were questioned by face to face interview method, the International Physical Activity Assessment Questionnaire (IPAQ) Long Form were used to measure the level of physical activity, and the Exam Anxiety Inventory was used to determine anxiety level.

International Physical Activity Questionnaire (IPAQ): The International Physical Activity Questionnaire was preferred in our study because it is frequently used in the literature, it is easy to use and cheap, and it gives information about the severity and amount of the activity. International Physical Activity Questionnaire (IPAQ) To determine the physical activity levels of participants aged 15-65, Craig et al. (12) was developed by. IPAQ 's study validity and reliability in Turkey was made by Ozturk (13). In the evaluation of all activities, it is taken as a criterion that each activity is performed for at least 10 minutes at a time. A score is obtained as "MET-minute / week" by multiplying the minutes, days and MET values. Physical activity levels are classified as physically inactive ( $<600$ MET-min / week), low level of physical activity (600-3000 MET-min / week) and sufficient physical activity (> 3000 MET-min / week) (12). 
Exam Anxiety Inventory: The scale developed by Speilberger to evaluate negative feelings and thoughts about the exam and test was adapted by Öner to Turkish $(14,15)$. Inventory consisting of a total of 20 items can be applied to all students and other individuals starting from the 4th grade. In the written or oral exams, the student scores how close the 20 expressions are to him, according to the quadruple scale prepared with Likert-type grading. The sum of these scores gives the total score related to the exam anxiety. In the survey with a score range of 20-80, the increase in points indicates that anxiety related to the exam has increased. It was thought that the anxiety score related to the exam would have a ceiling effect in the near term. For this reason, the study was carried out a week before the exams.

Statistical Methods: Mean, standard deviation, median, minimum, maximum value frequency and percentage were used for descriptive statistics. The distribution of variables was checked with kolmogorovsimirnov test. Kurskal-wallis test and mann-whitney $U$ test were used for the omparison of quantitative data. Spearman correlation test was used for the correlation analysis. Chi-Square test was used for the comparison of the comparison of qualitative data. SPSS 26.0 was used for statistical analyses.

\section{Results}

The average age of patients included in the study was $21.42 .9 \%(\mathrm{n}=75)$ were female and $57.1 \%(\mathrm{n}=100)$ were male (Table 1).

Table 1: Demographic characteristics of patients

\begin{tabular}{|c|c|c|c|c|c|c|c|c|}
\hline & \multicolumn{2}{c|}{ Min-Max } & \multicolumn{2}{c|}{ Median } & \multicolumn{2}{c|}{ Mean \pm sd/n-\% } \\
\hline \multirow{2}{*}{ Gender } & Age & 18,0 & - & 24,0 & 21,0 & 21,1 & \pm & 1,5 \\
\cline { 2 - 8 } & Female & & & & & 75 & $42,9 \%$ \\
\hline \multicolumn{2}{|c|}{ Exam Anxiety Inventory } & 22,0 & - & 62,0 & 39,0 & 37,6 & \pm & 10,3 \\
\hline \multirow{3}{*}{ IPAQ } & Inactive & & & & & 93 & $53,1 \%$ \\
\cline { 2 - 8 } & Minimal-Active & & & & & 44 & $25,1 \%$ \\
\cline { 2 - 8 } & Active & & & & & 38 & $21,7 \%$ \\
\hline
\end{tabular}

In the inactive, minimally active, active group, patients' ages did not differ significantly $(p>0.05)$. In the inactive group, the rate of female patients was significantly higher $(\mathrm{p}<0.05)$ than the minimally active and active group. Gender distribution between minimally active and active groups did not differ significantly (p $>0.05)$. In the inactive group, the test anxiety score was significantly more higher $(p<0.05)$ than the minimally active and active group. The test anxiety score did not differ significantly $(p>0.05)$ between the minimally active and active groups. Exam anxiety score in women was significantly higher $(p<0.05)$ than men. (Table 2)

Table 1: Comparison of demographic characteristics, Exam Anxiety Inventory scores before and after treatment between groups

\begin{tabular}{|c|c|c|c|c|c|c|c|c|c|c|c|c|c|c|c|}
\hline & & \multicolumn{4}{|c|}{ Inactive } & \multicolumn{4}{|c|}{ Minimal-Active } & \multicolumn{4}{|c|}{ Active } & \multirow{2}{*}{\multicolumn{2}{|c|}{$\mathbf{p}$}} \\
\hline & & \multicolumn{3}{|c|}{$\begin{array}{c}\text { Mean } \pm \text { sd/n- } \\
\%\end{array}$} & \multirow{2}{*}{$\begin{array}{c}\begin{array}{c}\text { Media } \\
\mathbf{n}\end{array} \\
21,0\end{array}$} & \multicolumn{3}{|c|}{$\underset{\%}{\operatorname{Mean} \pm \mathrm{sd} / \mathrm{n}-}$} & \multirow{2}{*}{$\begin{array}{c}\begin{array}{c}\text { Media } \\
\mathbf{n}\end{array} \\
21,0\end{array}$} & \multicolumn{3}{|c|}{$\underset{\%}{\operatorname{Mean} \pm \mathrm{sd} / \mathrm{n}-}$} & \multirow{2}{*}{$\begin{array}{c}\begin{array}{c}\text { Media } \\
\text { n }\end{array} \\
21,0\end{array}$} & & \\
\hline \multicolumn{2}{|c|}{ Age } & $\begin{array}{c}21 \\
0\end{array}$ & \pm & 1,5 & & $\begin{array}{c}21, \\
2\end{array}$ & \pm & 1,5 & & $\begin{array}{c}21, \\
1\end{array}$ & \pm & 1,5 & & $\begin{array}{c}0,70 \\
4\end{array}$ & K \\
\hline \multirow{2}{*}{$\begin{array}{l}\text { Gende } \\
\mathbf{r}\end{array}$} & $\begin{array}{c}\text { Femal } \\
\text { e }\end{array}$ & 50 & & $\begin{array}{c}53,8 \\
\%\end{array}$ & & 15 & & $\begin{array}{c}34,1 \\
\%\end{array}$ & & 10 & & $\begin{array}{c}26,3 \\
\%\end{array}$ & & \multirow{2}{*}{$\begin{array}{c}0,00 \\
6\end{array}$} & \multirow{2}{*}{$\begin{array}{c}\mathrm{X} \\
2\end{array}$} \\
\hline & Male & 43 & & $\begin{array}{c}46,2 \\
\%\end{array}$ & & 29 & & $\begin{array}{c}65,9 \\
\%\end{array}$ & & 28 & & $\begin{array}{c}73,7 \\
\%\end{array}$ & & & \\
\hline \multicolumn{2}{|c|}{$\begin{array}{l}\text { Exam Anxiety } \\
\text { Inventory }\end{array}$} & $\begin{array}{c}41 \\
8\end{array}$ & \pm & 9,5 & 41,0 & $\begin{array}{c}33, \\
2\end{array}$ & \pm & 9,0 & 30,0 & $\begin{array}{c}32, \\
3\end{array}$ & \pm & 9,2 & 30,0 & $\begin{array}{c}0,00 \\
0\end{array}$ & K \\
\hline
\end{tabular}

\section{${ }^{K}$ Kruskal-wallis (Mann-whitney $u$ test) $/{ }^{X^{2}}$ Chi-square test}

\section{Discussion}

The aim of this study was to determine the physical activity levels of university students and to test their relationship with anxiety. In our study, International Physical Activity Questionnaire was used to evaluate 
physical activity. The questionnaire, which has been shown to be valid and reliable by Öztürk, provides information about the type of physical activity in adolescents by grouping physical activity under the subheadings of work, transportation, home and leisure time. In addition, it allows to classify the level of activity as inactive, minimally active and very active (13). $53.1 \%$ of the individuals who participated in our study are place in the inactive group according to the IPAQ categorical classification. This result is similar to the results related to the level of physical activity found in studies conducted both in Europe and in our country (16-18). Unfortunately, the prevalence of inactivity has become an increasing problem both in our country and in the world. In their compilation study, Dumith et al. found that the level of physical activity decreased by an average of $7 \%$ each year in adolescent individuals. While the decrease in the level of physical activity was more common in boys in earlier, it has been reported that this is more common in girls today (19). This can lead to serious health problems, such as obesity. In order to deal with this problem, many institutions or organizations have made recommendations regarding the level of healthy physical activity. It is noteworthy that $53.1 \%$ of the participants were in the sedentary group in our study. Lack of physical activity can be associated with multiple factors. Among the reasons for the low levels of physical activity can be the less time spent on the exercise brought by today's modern lifestyle, watching TV, spending more time in front of the computer and video games. Season is among the factors affecting physical activity, rainy weather can be $2-4 \%$ and 10 degrees lower temperature can decrease physical activity level in $10 \%$ ratio (20). Our study was carried out between February and March. It is a period that covers the winter and spring months, and the fact that children are in the lesson period can be associated with the lack of physical activity. Female gender was statistically higher in the inactive group in our study. It was observed that female students were place in a more sedentary group than men. This situation overlaps with other studies in the literature that find the physical activity level of men is higher than girls $(16,17,21,22)$. It can be said that the most obvious biological variable of physical activity behavior is gender. The fact that boys are more involved in physical activity can be explained by possible mechanisms such as body composition being different from girls during growth, differences in motor abilities, and being more social for participation in sports and physical activity. Compared to Sallis et al, this situation becomes more evident from the age of 16 (23). It is known that the frequency of physical activity and participation in sports activities generally increase the quality of life, regulate sleep, and provide a positive effect in coping with stress. The positive effect of performing regular sports on anxiety has been shown in many studies $(24,25)$. Although anxiety is described as a necessary emotional state in dealing with problems, by many individuals it defines as an inadequacy situation. Among the many epidemiological studies examining the relationship of anxiety with physical activity, although there are studies that are physically active and report similar symptoms of anxiety among the sedentary group, the number of publications that show that physical activity reduces anxiety symptoms in recent publications is rapidly increasing (24). In our study, only the relationship between exam-related anxiety and physical activity level and regular sports participation were examined. In our study, we found that subjects in the inactive group had higher levels of exam anxiety than minimally active and active groups. The results were found to be compatible with the studies in the literature. De Mello et al. In a large-scale epidemiological study conducted on adult individuals in 2013, 1042 individuals with an average age of $41.9 \pm 14.4$ years were evaluated, and the relationship between symptoms of depression and anxiety with variables such as age, gender, socioeconomic status, duration of education was investigated. It was observed that the frequency of occurrence of anxiety and depression symptoms was twice as high in participants without regular physical activity (26). There are also studies showing the exact opposite of the relationship between physical activity level and anxiety. Tao et al. in research they have done reported that the increase in severe physical activity level is a risk factor for alcohol use, suicidal tendency, general psychological diseases and hostile attitude (27). As a result, in our research that we made revealed that university students' physical activity levels were quite low especially in female students and there was a statistically significant relationship between physical activity level and anxiety. The relationship between physical activity level and depression and anxiety can be better enlightened with more comprehensive and more controlled studies in this area.

\section{References}

[1.] Mowbray CT, Megivern D, Mandiberg J M, Strauss S, Stein CH, Collins K veLett R. Campus mental health services recommentations for change. American Journal Of Orthopsychiatry. 2006;76(2): 226237. 
[2.] Grant KE, Compas B E , Thurm A E , Mcmahon S D ve Gipson P Y. Stressors and child and adolescent psych opathology: measurementissuesandprospectiveeffects . Journal of Clinical Child \&AdolescentPsychology. 2004;33: 412 - 425.

[3.] Kilpelainen TO, Qi, L., Brage, S., Sharp, S.J., Sonestedt, E., Demerath, E. ve diğerleri. Physical activity attenuates the influence of FTO variants on obesity risk: a meta-analysis of 218,166 adults and 19,268 children. Public Library of Science Medicine. 2011; 8(11), e1001116.

[4.] Denton SJ, Trenell, M.I., Plotz, T., Savory, L.A., Bailey, D.P., Kerr, C.J. cardiorespiratory fitness is associated with hard and light intensity physical activity but not time spent sedentary in 10-14 year old schoolchildren: the HAPPY study. Public Library of Science Medicine One. 2013;8(4): e61073.

[5.] Günay O, Öncel, Ü., Erdoğan, Ü., Güneri, E., Tendoğan, M., Uğur, A. ve diğerleri. Lise son sinıf öğrencilerinde durumluk ve sürekli anksiyete düzeyini etkileyen faktörler. Sağlık Bilimleri Dergisi. 2008;17(2): 77-85.

[6.] Dündar S, Yapıcı, Ş.,Topçu, B. Üniversite öğrencilerinin bazı kişilik özelliklerine göre sınav kaygısının incelenmesi. Gazi Eğitim Fakültesi Dergisi 2008;28(1): 171-186.

[7.] Meltzer LJ, Logan, D.E.,Mindell, J.A. Sleep patterns in female adolescents with chronic musculoskeletal pain. Behavioral Sleep Medicine. 2005;3(4): 193-208.

[8.] Gerber M, Brand S, Ellıt C, Holsboer-Trachsler E ve Pühse U. Aerobıc exercise, ball sports, dancing, and weight liftıng as moderators of there lationship between stres and depressive symptoms: an exploratorycross-sectional study with swiss university students. Perceptual\& Motor Skills. 2014;119(3): 679-697.

[9.] Thome J, Espelage D. Relations among exercise, coping, disorderedeating, and psychological health among college students. EatBehav. 2004;5(4): 337-351.

[10.] Balkin R.S, Tietjen-Smith T, Caldwell C ve Yu-Pei S.The utilization of exerciset odecrease depressive symptoms in young adult women. Adult span Journal. 2007;6(1): 30-35.

[11.] S,Wiegel J R, Mundt M, Brown D, Saewyc E, Heiligenstein E,Harahan B,Fleming M. Depression and suicide1deationamong students accessing campus health care. American Journal of Orthopsychiatry. 2011;81(1): 101-107.

[12.] Craig CL, Marshall AL, Sjöström M, Bauman AE, Booth ML, Ainsworth BE, Pratt M, Ekelund U, Yngve A, Sallis JF, Oja P. International Physical Activity Questionnaire: 12-Country ReliabilityandValidity. MedicineScienceand Sports Exercise. 2003;35(8): 1381-1395.

[13.] Öztürk M. (2005) Üniversitede eğitim-öğretim gören öğrencilerde Uluslararası Fiziksel Aktivite Anketinin geçerliliği ve güvenirliği ve fiziksel aktivite düzeylerinin belirlenmesi. [Yüksek Lisans Tezi]. Ankara: Hacettepe Üniversitesi Sağlık Bilimleri Enstitüsü.

[14.] Öner, N. Sınav kaygısı envanteri el kitabı. Yüksek Öğretimde Rehberliği Tanıtma ve Rehber Yetiştirme Vakfı Yayını 1990: s. 1-2.

[15.] Spielberger, C.D. (1980). Test anxiety inventory: Wiley Online Library.

[16.] Bauman, A., Bull, F., Chey, T., Craig, C.L., Ainsworth, B.E., Sallis, J.F. ve diğerleri. International Journal of Behavioral Nutrition and Physical Activity. International Journal of Behavioral Nutrition and Physical Activity. 2009;31(6):21.

[17.] Karaca, A., Caglar, E.,Cinemre, Ş. Physical activity levels of the young adults in an economically developing country: The Turkish sample. Journal of Human Kinetics. 2009;22(1): 91-98.

[18.] Vašíčková, J., Groffik, D., Frömel, K., Chmelík, F., Wasowicz, W. Determining gender differences in adolescent physical activity levels using IPAQ long form and pedometers. Annals of Agricultural and Environmental Medicine: AAEM. 2012;20(4): 749-755.

[19.] Dumith, S.C., Gigante, D.P., Domingues, M.R., Kohl, H.W., 3rd. Physical activity change during adolescence: a systematic review and a pooled analysis. International Journal of Epidemiolog. 2011;40(3): 685-698.

[20.] Bélanger, M., Gray-Donald, K., O'loughlin, J., Paradis, G., Hanley, J. Influence of weather conditions and season on physical activity in adolescents. Annals of Epidemiology. 2009; 19(3): 180-186.

[21.] Jekauc, D., Reimers, A.K., Wagner, M.O., Woll, A. Prevalence and socio-demographic correlates of the compliance with the physical activity guidelines in children and adolescents in Germany. BMC Public Health. 2012; 12(1): 714. 
[22.] Jago, R., Anderson, C.B., Baranowski, T., Watson, K. Adolescent patterns of physical activity: Differences by gender, day, and time of day. American Journal of Preventive Medicine. 2005;28(5): 447-452.

[23.] Sallis, J.F., Prochaska, J.J.,Taylor, W.C. A review of correlates of physical activity of children and adolescents. Medicine and Science in Sports and Exercise. 2000;32(5): 963-975.

[24.] Canan, F.,Ataoğlu, A. Anksiyete, depresyon ve problem çözme becerisi algısı üzerine düzenli sporun etkisi. Anatolian Journal of Psychiatry. 2010;11(38): 38-48.

[25.] Taylor, C.B., Sallis, J.F., Needle, R. The relation of physical activity and exercise to mental health. Public Health Reports. 1985; 100(2): 195.

[26.] De Mello, M.T., Lemos, V.d.A., Antunes, H.K.M., Bittencourt, L., SantosSilva, R., Tufik, S. Relationship between physical activity and depression and anxiety symptoms: a population study. Journal of Affective Disorders. 2013; 149(1): 241-246.

[27.] Tao FB, Xu ML, Kim SD, Sun Y, Su PY, Huang K. Physical activity might not be the protective factor for health risk behavi oursand psycho pathological symptoms in adolescents. J Paediatr Child Health. 2007; 43(11): 762-7. 